\title{
The effectiveness of community radio infrastructure to support disaster preparedness (case study of community radio in Merapi Volcano, Yogyakarta, Indonesia)
}

\author{
Siti Hadiyati Nur Hafida ${ }^{1, *}$, Bakti Setiawan ${ }^{2}$, and Rose Anna $\mathrm{A}^{1}$ \\ ${ }^{1}$ Geography Education, Universitas Muhammadiyah Surakarta, Jl. Ahmad Yani, Pabelan, Kartasura, Surakarta 57162, Jawa Tengah, \\ Indonesia \\ ${ }^{2}$ Architecture Technic, Universitas Gadjah Mada, Jl. Grafika No. 2 Yogyakarta 55281, Yogyakarta, Indonesia
}

\begin{abstract}
The updated information about the disaster situation is one of the crucial aspects for people who live in hazardous areas. The community radio is one of the communication media which is required by the community to receive the fast and accurate information its updated condition of the disasters. The aim of this study is to evaluate the effectiveness of community radio for supporting disaster preparedness activities. This study was conducted based on the qualitative descriptive approach where the respondents are the community, the managers of community radio and the Non-Government Organization of Combine Resources Institution. The data for the qualitative analysis was obtained by interviews, fills the questionnaires, and observation of the above respondents. The result of this study shows the high effectiveness of the community radio for supporting the disaster preparedness, i.e. $63.6 \%$. Its effectiveness is influenced by the utilization, management and economy impact of the community radio. The community radio which is established by the community is more effective to use compare others communities. Each community knows what they need to maintain their lives. The community also gives a positive response to present the community radio. Its positive response results in the ability of the community to adapt to the community radio. The community requirement which is followed by the response and their adaptation encourage the community to use community radio in more effective.
\end{abstract}

\section{Introduction}

Disaster is not a new phenomenon. Disasters occur regardless of time and place. Indonesia is a vulnerable country for all types of disaster. Disaster is defined as a condition of destruction and shock that influences the social structure. The affected people may not be able to cope and requires help from outsiders [1]. There are many activities cannot be conducted during and after the disaster as well and results costs the community in both of socially and economically. Despite the disaster produce the large impact on the social community, however, there are still a lot of people residing in hazardous areas.

Until nowadays, there has been the change in the society's opinion respect to the impact of the disaster. People have been thought that the disaster is the natural phenomenon, instead of God's act [2]. The change of this opinion has encouraged people to find new solutions to minimize the negative impact of disasters. The behavioral paradigm emphasizes the geographical causes of disasters and also on the use of technology or infrastructure to reduce damage caused by disaster impacts [3].

Observing the reality of the people living in hazardous areas suggest that the community should have the awareness to the disaster preparedness. Applied the technology may become a solution to improve disaster preparedness in the community. Community preparedness is known as an important aspect to cope with the disasters. If the community has a good awareness of the disaster preparedness, the negative impact of the disaster may be minimized. In the area of high intensity of the hazard and vulnerability, when they can make good preparation for the disaster, the negative impact can be suppressed [4].

Actually, the natural disaster is a complex issue when it handled manually. Therefore, the effort for improving the disaster preparedness will more effective if it is supported by relevant infrastructures. The Infrastructure is the facilities for supporting the community, organization, or society to properly functionally of the economic productivity [5]. The infrastructure can be used to support the information broadcasting about the disasters. Unfortunately, in many cases, most of the infrastructures damaged when the disaster occurred. The radio facilities are one type of infrastructure that can still operate during the disaster. Other than that, to decrease effect gaps and to reach to the least privileged poor people, traditional mass media will be used, like radio infrastructure [6]. The radio infrastructure may quickly broadcast the information to the community, even to remote areas.

Corresponding author: nur.hafida@ums.ac.id 
One type of radio which commonly used by the community is known as a community radio. The community radio is a radio infrastructure which is operated by and for the society [7]. It remains as the basis of a new paradigm of development communication [6]. The community radio is a unique communication mediwherea. The management and programs of the radio are operated by and for the advancement of community members who live in remote areas [8]. All programs of community radio are produced by the local community, in local language or dialect, and usually discussing relevant local issues.

The development of community radio has indicated the progress in information technology and the development paradigm has emphasized on participation [9]. The establishment of community radio should refer to two aspects, namely the existence of society and community participation [10]. Participation means engaging in the whole activity (active) and not just participating (passively). The existence of a community that is willing to be active in managing radio and community participation must be balanced, both as part of broadcasting and as listeners, because it could have an effect on radio management in the future. Community radio is a key element in the empowerment, development, and consolidation of local communities [11], and therefore, community radio requires good management to sustain.

Activities in the community radio may result in the significant changes in people's lives [9]. By the community radio, may play not only supportive roles in achieving the targets but also contribute for creating new opportunities for the development of their village. The community radio broadcast the programmes on the updated issues. The programs will have an impact on activities relating to the eradication of extreme poverty, achieving universal primary education, promoting gender equality, reducing child mortality, combating HIV/AIDS, ensuring environmental sustainability and developing an international partnership for development [6].

The efforts to improve disaster preparedness in the community is conducted by utilizing this community radio. It is expected will the impact on increasing public awareness and disaster risk management. Utilization of community radio is begun with the community understanding of the disaster and the community radio itself. It community understanding will greatly affect the attitude and behavior of people in making decisions. The community understanding is influenced by the difference of the information received by individuals, the difference of the attitude, and the interests of each individual [12]. The differences will give differed assessments about the disaster and will affect one's decision. The community understanding in utilizing community radio infrastructure will be based on individual capacity and quality [13].

The community radio will affect the community response [14]. The community response can be measured by the perceptions, attitudes, and behavior of the community [15]. The community response may be positive in terms of willingness to accept and support the community radio infrastructure, but it may also be negative. They may reject the establishment of the community radio infrastructure and could even result in horizontally conflict in the community [16]. The community responses and their adaptation to community radio infrastructure will affect community participation in infrastructure management. The community adaptation will affect the individuals or communities when responses to the positive or negative effects of its infrastructure.

The management activities will influence several aspects such as planning, organizing, actuating, and controlling of the community radio. The management has to conducted to achieve certain goals effectively and efficiently. The management can deal with issues due to frequent and elaborate changes [17]. Therefore, the management must be initiated with the utilization of the infrastructure by the community such that the community can perform the management in accordance with the conditions of their area. A good community radio management will encourage the effectiveness of community radio to support disaster preparedness. Increasing the intensity of management will reduce the presence of risk factors [18]. As shown in Fig. 1.

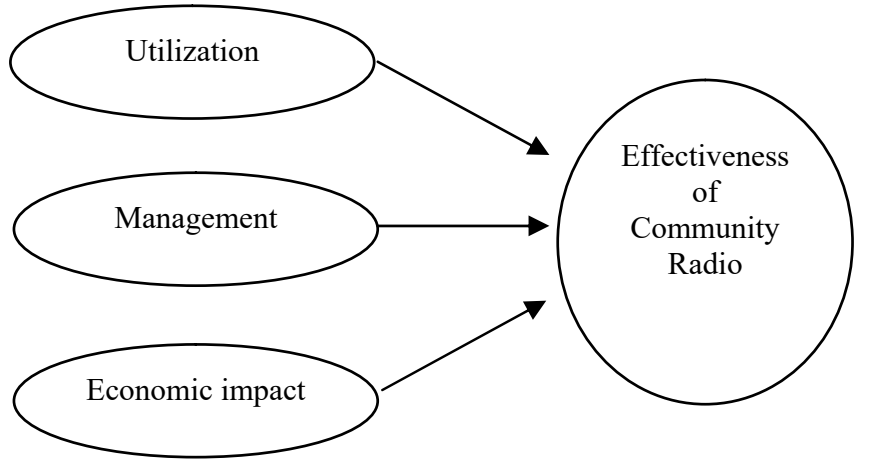

Fig. 1. Theoretical/conceptual model of research.

\section{The material and method}

The aim of this study is to evaluate the effectiveness of the community radio infrastructure in the community disaster preparedness based on the qualitative descriptive approach. The study was conducted by field investigation to the hazardous area III of Merapi Volcano using sampling technique. The respondents were community radio managers of two different of the community radio, communities with consist of 30 people and Non-Governmental Organization (NGO) of Combine Resources Institute.

The variables used in this study are the utilization, management and economy impact of community radio. The utilization means the use of community radio by the community to support their daily activities. The level of utilization of the infrastructure of the community radio is influenced by four factors, namely: a comprehension of the community, the community requirements, the response and adaptation of the community. The management is the activities for supporting the 
development of community radio infrastructure. These four factors might influence management include planning, organizing, actuating and controlling. The economic impacts are used to determine whether the community radio is a burden or not for the community so that it can be known the effectiveness of community radio.

The data for qualitative analysis was collected by interviews the respondents, full fill the questionnaires and observe the community activities. Interviews were conducted with community radio managers and the NGOof Combine Resources Institution, while the questionnaires were conducted to the community to measure the usage of community radio and community opinions on community radio management. This study applied the Likert scale as a measurement scale to measure the qualitative the community answers which is related to the community radio.

The available data were analyzed by using the data reduction, data presentation and conclusion or verification. In general, the qualitative data analysis is an ongoing process requiring continuous reflection of data, asking analytical questions and writing notes throughout the study [19].

\section{Result and discussion}

\subsection{The utilization of community radio}

Fig. 2. shows a good comprehension of the disaster based on the interview of two community radio. These two community radios were located in hazardous area III of Merapi volcano. These communities have already understood the disaster in their region and also the impact of it disasters. The existence of this comprehension encourages the community to always receive the updated disaster information so the need for information of disaster.

The high demand for the updated disaster information was not accompanied by the response of the community towards community radio. The communities living around Lintas Merapi FM community radio gave the very good response to Lintas Merapi FM community radio. They can well-adapted with Lintas Merapi FM community radio. The community can participate in the management of Lintas Merapi FM community radio so that many programs of the community radio, both on-air and off-air, can encourage the community to move forward.

The motto of Lintas Merapi FM community radio is "no matter how lucky a forgetful person is, a cautious person will still be luckier". Its motto has encouraged the community to always get the updated information regarding the condition of Merapi volcano. The community puts more trust in Lintas Merapi FM rather than the mass media. Many mass media that exaggerate the information about the disaster which is easily causing panic in the community.

The communities who live around Gema Merapi FM community radio actually have well responded to their community radio. They have already agreed that the community radio is updated information facility for the crucial in hazardous areas. Even though initially the respond of the community is relatively well. Unfortunately, due to lack variety of the activities, it community goes to be skeptical. The community radio cannot adapt to the community and the community not involved in the management of the community radio. The community is reluctant to be involved in community radio management so that the activity of community radio only managed to spread the information without affecting the lives of the community.

The Gema Merapi FM community radio has a good vision and mission. Their vision and mission are "being empowered, cultured, and cautious". Empowered means that the community radio is expected to help other people become more self-reliant in all aspects of the life. The cultured society is interpreted as an incentive to act in accordance with the local norms and rules that apply without damaging the surrounding environment. Remain cautious means that the community radio can post the balanced information about Merapi Volcano in order to reduce the risk of the disaster.

The vision and mission of Gema Merapi FM community radio may be fulfilled if the community around the community radio is interested in managing Gema Merapi FM community radio. The utilization of community radio has to balance among the comprehension, need, response and adaptation. When there is even only one low aspect, then the community radio would not be able to change the community's lives, particularly in supporting disaster preparedness.

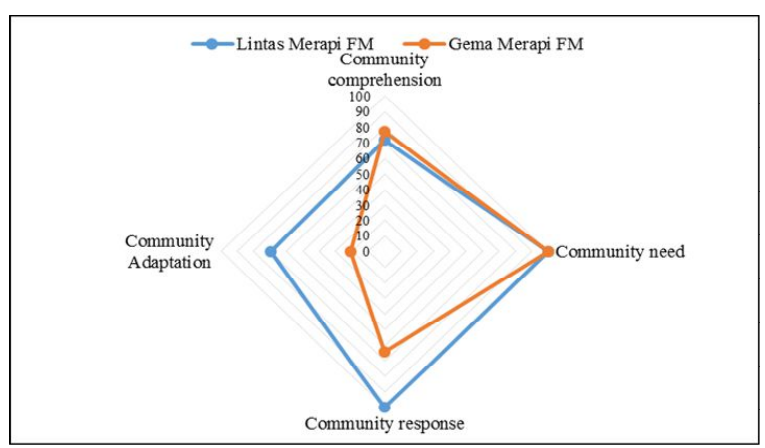

Fig. 2. Comparison of utilization of two community radio Source: analysis, 2016

\subsection{Management of community radio}

Based on Fig. 3. it is noticeable that the Lintas Merapi community radio has good management when is compared to the Gema Merapi FM community radio. Both of these community radios are in disaster-prone areas III of Merapi Volcano and both of them represent each district. The Lintas Merapi FM is located in Klaten District, Central Java, while Gema Merapi FM is located in Sleman Regency, Yogyakarta.

Management of the Lintas Merapi FM community radio has actively involved the communities and it can be seen from the community involvement in the planning stage. Only a few people who were actively planning and 
managing the Lintas Merapi FM community radio at the beginning. However, as time went many people are getting involved in community radio management. The community radio set the goals, programs, systems, and budget. The Lintas Merapi FM community radio not only have on-air activities, but there are also off-air activities that will support the on-air activities, such as disaster training, computer training, and agricultural training.

The contents of the broadcast during the on-air activities are prioritized in the theme of the disaster mitigation, where the community is given the basics knowledge of disaster and disaster management tips. The information about weather changes and activities of Merapi Volcano are always broadcasted every day from 12.00 a.m to 12.00 p.m. The Lintas Merapi FM community radio not only focus on the efforts of the disaster mitigation, but they also broadcast the general information such as emerging issues in the community such as the problem of smoking, promiscuity, education up to the general election, entertainment and advertising community service. When Merapi Volcano is showing signs of alert, the Lintas Merapi FM community radio will broadcast the news for 24 hours, and there is no coercion in the broadcast schedule.

The Gema Merapi FM community radio programs are more focused on off-air activities, while on-air activity only carried out in the emergency state. The information delivered at on-air activities is the information that goes around the community radio, such as the health schedules, settlement condition, and Merapi Volcano condition. The used of HT is more often compared with radio. The radio broadcast is rarely done because of some operational problems in the on-air activities, among others: the absence of broadcasters, lack of important broadcast program and lack of funds for financing electricity.

The off-air activities program conducted by the Gema Merapi FM community radio includes the increasing of the capacity of coping with disaster/disaster training, emergency care, English language training, entrepreneurial training, travel training and cultural training. The aim of the off-air activity is the community has to receive the knowledge and understanding about the disaster such that the community may in a better act in every activity. The managers of Gema Merapi FM community radio considers the community radio would not be effective if the activities only conducted the on-air activity. Sometimes the on-air activities actually may disturb the community in social aspect such as the school children who become the broadcasters have to back home at late night and began the habit of smoking because seeing other adult broadcasters smoking.

The success and failure of the programs depend on the content of the news in the mass media, its aim and the type of ownership [6]. The Lintas Merapi FM community radio becomes one of media infrastructure that is trusted by the community when the disaster occurs. The people around the Lintas Merapi FM community radio are familiar with the programs and radio broadcast schedules. However, only a few people who know the off-air activities program of the Lintas Merapi FM community radio. Unlike the Lintas Merapi FM community radio, the Gema Merapi FM community radio has been rarely doing on-air activities causing unfamiliarity among the community member about the radio broadcast program, the community more familiar to off-air activities program of the Gema Merapi FM community radio.

Community involvement in information search or management in Lintas Merapi FM community radio has been good. Lintas Merapi FM community radio also has good relations with the surrounding community, thus indirectly the public will participate and monitoring toward the Lintas Merapi FM community radio. Communities living around Lintas Merapi FM community radio always supervise the management of Lintas Merapi FM community radio. The local community already considers the Lintas Merapi FM community radio as part of the community life. A sense of belonging in the community is the result of the management transparency from radio administrators. The community ultimately willing and offer sincere help to the community radio either with the help of funds, time and effort, they do not consider that community radio as an extra burden on their lives.

In general, if the relationship between the managers and the community is relatively good, it will give a positive impact to the community's involvement in the organization. However, it does not apply to the Gema Merapi FM community radio.

The Leadership in the Gema Merapi FM community radio is weak, it is evidenced by the small number of the radio managers. Decreasing number of the radio managers certainly influenced by the role of the leader in the organization. The relationship between the managers of the Gema Merapi FM community radio is good, however, the involvement of community monitoring is still very low. The people living around the Gema Merapi FM community radio are started to think more about things and activities with economic value, so they prefer activities that can generate money compared to activities that do not make money. This perspective eventually led people to avoid being involved in the management of the Gema Merapi FM community radio.

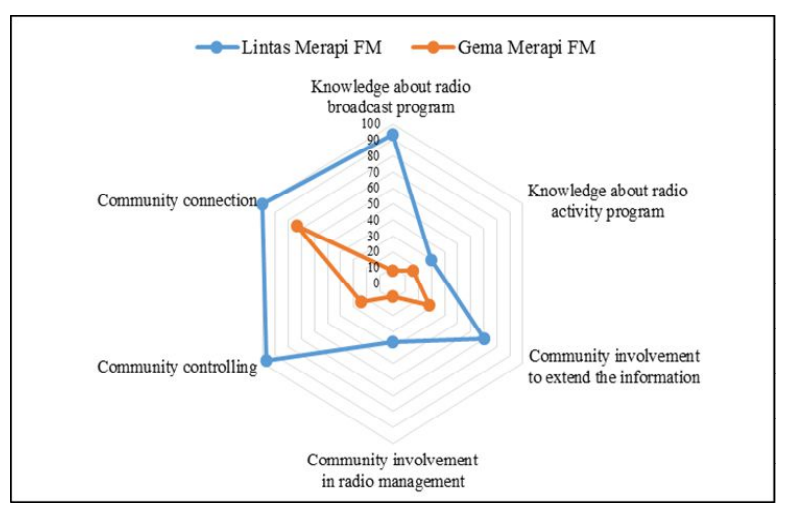

Fig. 3. Management comparison of two community radio Source: analysis, 2016 


\subsection{Economic of community radio}

Table 1. shows the capability of the Lintas Merapi FM community radio to collect funds from the community to support community radio activities. On the other hand, the Gema Merapi FM community radio can not persuade the community to involved in the activities of community radio. The Gema Merapi FM community radio does not have sufficient funds to support on-air activities, forcing them to hold more off-air activities. The people's contribution to support the radio activities indicates their sense of belonging towards the community radio. Hopefully, this will lead to increased involvement in the radio management.

Many off-air activities programs were carried out by the Lintas Merapi FM community radio and the Gema Merapi FM community radio causing these two community radios to have network markets and access to a wider market. The network consists of not only the governments but also the private sector. They were involved in activities that were organized by the community radio. The existence of these networks can be beneficial to the community radio.

The community more interested in the community radio if the community radio prepares the programs that can profit. The Lintas Merapi FM community radio provides Wi-Fi to the community. Considering the geographic condition, Wi-Fi becomes one facility that is needed by the community in remote areas. The Lintas Merapi FM community radio also has CCTV infrared to monitor Merapi volcano condition. These tools are used to encourage community disaster preparedness.

Table 1. Economic of community radio

\begin{tabular}{|c|l|l|l|}
\hline No & Variable & $\begin{array}{l}\text { Lintas Merapi } \\
\text { FM }\end{array}$ & $\begin{array}{l}\text { Gema Merapi } \\
\text { FM }\end{array}$ \\
\hline 1 & $\begin{array}{l}\text { Ability to } \\
\text { accumulate } \\
\text { the funds } \\
\text { able to } \\
\text { accumulate } \\
\text { the funds } \\
\text { from the } \\
\text { community }\end{array}$ & $\begin{array}{l}\text { Good, been } \\
\text { source of the } \\
\text { fund is from } \\
\text { off-air } \\
\text { activities. }\end{array}$ \\
\hline 2 & $\begin{array}{l}\text { Ability to } \\
\text { distribute the } \\
\text { funds }\end{array}$ & $\begin{array}{l}\text { Good, } \\
\text { efficiently } \\
\text { used to run } \\
\text { programs } \\
\text { which are } \\
\text { useful for the } \\
\text { community }\end{array}$ & $\begin{array}{l}\text { Poor, radio } \\
\text { program only } \\
\text { carried out on } \\
\text { a special } \\
\text { occasion when } \\
\text { needed. }\end{array}$ \\
\hline 3 & $\begin{array}{l}\text { Ability to } \\
\text { generate } \\
\text { profits }\end{array}$ & $\begin{array}{l}\text { Moderate, } \\
\text { programs are } \\
\text { less profitable }\end{array}$ & $\begin{array}{l}\text { Good, some of } \\
\text { the programs } \\
\text { are able to } \\
\text { generate profit }\end{array}$ \\
\hline 4 & $\begin{array}{l}\text { The ability } \\
\text { of network } \\
\text { and market } \\
\text { access }\end{array}$ & $\begin{array}{l}\text { Good, radio } \\
\text { programs are } \\
\text { capable of } \\
\text { attracting the } \\
\text { sponsors }\end{array}$ & $\begin{array}{l}\text { Good, more } \\
\text { off-air } \\
\text { activities } \\
\text { which interest } \\
\text { the sponsors }\end{array}$ \\
\hline
\end{tabular}

\subsection{The effectiveness of community radio}

The effectiveness of community radio was measured by the utilization, management and economic impact of the community radio. Fig. 4. shows that $56.57 \%$ of the respondents consider that the Lintas Merapi FM community radio rarely provides disaster training. The people often get disaster training from the government and BPBD, however, they felt that their community radio is effective in improving community disaster preparedness $(96.67 \%)$. This is because the disaster information and the condition of Merapi Volcano are daily broadcasted, with updated information. The communities are able to cope with disaster better, knowing they have reliable information.

All respondents found that the Lintas Merapi FM community radio has not been able to affect the economic life of the community. The role of the community radio still limited as a medium of information dissemination about the disaster. Therefore, the work plan which is currently being carried out will be more focused on the economic value that will be received by the community. The community will receive training in organic agriculture (coffee, ginger, and onions) that can be used as a business opportunity for the community.

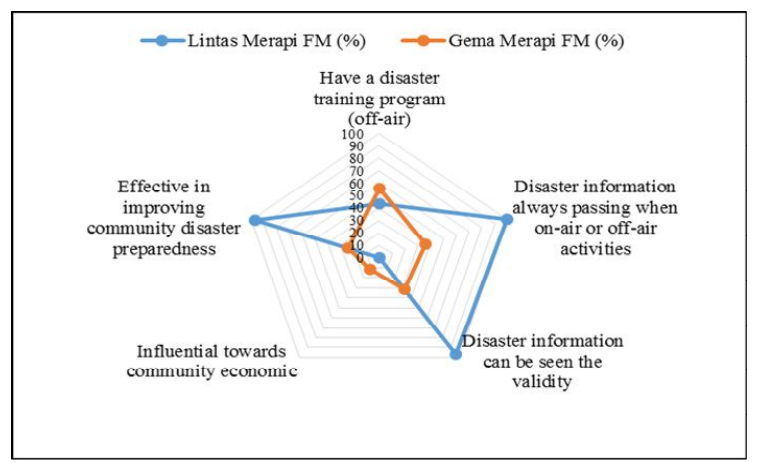

Fig. 4. Congruence service of community radio Source: analysis, 2016

According to the Fig. 4. 56\% of respondents had attended programs of activities organized by the Gema Merapi FM community radio, while only $36 \%$ who think that the Gema Merapi FM community radio has disseminated the disaster information to the community through on-air activities. This proves that the off-air activities programs are more frequently performed than the on-air activities. The community considers that the community radio has not been effective in improving community disasters preparedness because the community always assumes that the Gema Merapi FM community radio is the organization radio, not the community radio. Even with frequent entrepreneurship training, the Gema Merapi FM community radio was still unable to improve the economic life of the community. The community has not been able to apply the knowledge that they get into a business opportunity. 


\section{Conclusions}

The effectiveness of community radio for improving the community disaster preparedness was classified as the high category, i.e. $63.6 \%$. Based on the results of the analysis shows that the Lintas Merapi FM community radio has a better effectiveness than the Gema Merapi FM community radio. The main aspect that influences ineffectiveness is the development initiator of the community radio. The Lintas Merapi FM was built by the community so, the Lintas Merapi FM will have a better level of utilization and management when compared with the community radio was built by the government or organization, like the Gema Merapi FM.

The communities are easier to respond and adapt to the community radio which was built by the community. Its because the community knows the program of the community radio so the community more believes with the information broadcasted by the community radio. The main problem in the management of community radio is the economy, community radio cannot provide economic benefits for the community. Infrastructure will be sustainable if it can provide an economic impact to the community.

\section{References}

1. Rautela. P. Disaster Prevention and Management, Redefining Disaster: Need for Managing Accidents as Disasters, 15 (5),799-809 (2006)

2. Ibrahim Mohamed Shaluf. Disaster Prevention and Management, Disaster Types,16 (5), 704-717 (2007)

3. Smith, K. Environmental Hazards: Assessing Risk and Reducing Disaster (London: Routledge, 2007)

4. Agus Indiyanto and Arqom Kuswanjono. Construction of a Community Disaster Resilient (Bandung: Mizan Reader, 2012)

5. Dr. Larry Beeferman and Dr. Allan Wain. 2013. Infrastructure Defining Matters. DOI: $10.2139 /$ ssrn. 2714308

6. Kaberi Gayen. Media Asia, Community Radio in Bangladesh The Policy and The Spirit, 39 (1), 3239 (2012)
7. Louie Tabing. How to do Community Radio: A Primer For Community Radio Operators (New Delhi: UNESCO, 2002)

8. Rochmad Effendy. Komunikator. Role of Community Radio in Developing Civic Community, 5 (1), 1 - 26 (2013)

9. Seidu Al-hasaan, Alhassan Andani, and Abdulai Abdul-Malik. The Journal of Field Actions Science Reports. The Role of Community Radio in Livelihood Improvement: The Case of Simli Radio, 5, 1 - 6 (2011)

10. Masduki. Communication Studies. Development and Problematic of Community Radio in Indonesia, 1 (1), 73 - 86 (2004)

11. Niamh Gaynor and Anne O'Brien. Community Development Journal. Because It All Begins with Talk: Community Radio as a Vital Element in Community Development, 47 (3), 436 - 447 (2011)

12. Su Rito Hardoyo, etc. The Strategy of Community Adaptation in Disaster Flood Sea Water Tide in Pekalongan City (Yogyakarta: MPPDAS UGM, 2011)

13. IFRC. Characteristics of a Safe and Resilient Community. Community-Based Disaster Risk Reduction Study (Geneva: IFRC, 2011)

14. Nurjanah, etc. Disaster Management (Bandung: Alfabeta, 2013)

15. J.A.R. Jati1, Asep Mulyadi. Geography Education. Study of Space and Public Response to Aviation Activities Around of Runway Airport Husein Sastranegara, 15 (2), 66 - 72 (2015)

16. Sunyoto Usman. Sociological Essays of Social Change (Yogyakarta: Student Library,2015)

17. Xianfeng, Q., Boxiong, L., \& Zhenwei, G. Tsinghua Science and Technology. Conceptual Model of IT Infrastructure Capability and Its Empirical Justification, 13 (3), 390-394 (2008)

18. Zwikael, O., \& Ahn, M. Risk Analysis. The Effectiveness of Risk Management: An Analysis of Project Risk Planning Across Industries and Countries, 31 (1), 25-37 (2011)

19. John W Creswell. Research Design Qualitative, Quantitative, and Mixed Approaches (Yogyakarta: Student Library, 2014) 